\title{
Handbook of Research Methods for Tourism and Hospitality Management
}

Edited by

Robin Nunkoo

Associate Professor, Department of Management, University of Mauritius

HANDBOOKS OF RESEARCH METHODS IN MANAGEMENT

\section{A. E Edward Elgar}

Cheltenham, UK • Northampton, MA, USA 


\section{Ethical issues in tourism and hospitality research Gianna Moscardo}

\section{INTRODUCTION}

Most of the discussion about ethics in tourism has focused on the ethics of tourism practice and the actions of tourists and tourism developers, planners, and businesses (see Fennell, 2006). Very little attention has been paid to research ethics in the writings of tourism academics (Botterill and Platenkamp, 2012; MacCannell, 2012; Moscardo, 2010). This could be attributed in part to the multidisciplinary nature of the field, with tourism researchers from disciplines such as anthropology, sociology, psychology, and geography guided by the various ethical codes and principles existing within these disciplines. The landscape of tourism research training is changing, however, with a significant increase in doctoral studies where tourism is considered the discipline. This raises the question of where these researchers find their ethical frameworks (Moscardo, 2010). The lack of apparent interest in tourism research ethics could also be attributed to a tourism-centric bias where researchers focus solely on what is happening within the established tourism literature rather than also maintaining connections with trends in the wider academic literature (Melissen and Koens, 2016; Moscardo, 2014). It is also possible that some tourism researchers follow their respective institutional regulations with regard to research ethics, assuming no need for critical discussion of ethical issues beyond these institutional requirements. Such critical discussion, however, does exist outside these regulations and beyond tourism, and it offers notes of caution, challenges, and suggestions for conducting more ethical tourism research.

Tourism research also has a number of characteristics that have been connected in the wider literature to ethical questions. For example, much tourism research is applied, with many instances where the distinction between researcher, consultant, and advocate are blurred (Baines et al., 2013). A significant portion of tourism research is conducted with, and about, different cultural groups, including Indigenous peoples, which also raises ethical concerns (Vanclay et al., 2013). The growth of data analytics and netnography in tourism research gives rise to additional ethical questions for consideration (Hammersley and Traianou, 2012). Given this context it seems timely to critically reflect on ethical issues in tourism and hospitality research. Tourism is also characterised by its use of a wide range of research designs to study a large number of variables with a lack of established strategies (Ioannidis, 2005). Taken together, these elements suggest a need to consider research ethics for tourism in more detail.

This chapter briefly introduces a definition, some historical context and an overview of the regulatory environment for research ethics before reviewing existing discussions of tourism research ethics. The chapter then suggests a set of ethical questions that tourism researchers need to consider, and discusses each of these guided by relevant social science literature and then linked to examples drawn from the author's experience. It concludes by offering some suggestions to guide more ethical tourism research practice in general. 


\section{RESEARCH ETHICS OVERVIEW}

Hammersley and Traianou (2012, pp. 16-17) provide a broad definition of research ethics as 'a set of principles that embody or exemplify what is good or right, or allow us to identify what is bad or wrong'. Botterill and Platenkamp (2012, p. 75) provide a little more detail, defining research ethics as 'a moral stance that seeks to promote high professional standards in social research and protect both respondents and researcher from harm'. Research ethics are based in the wider literature on ethics in general (see Brooks et al., 2014, for more detail). As such, the need to be ethical in research practice has a long history and research ethics codes (RECs) have emerged with the development of various disciplinary and professional associations (Hammersley and Traianou, 2012). In the twentieth century a number of controversial research studies conducted in Nazi Germany and the United States of America (USA) prompted the development of national regulation and administration programmes for research ethics (Hammersley and Traianou, 2012). Researchers in most parts of the world are now required to get approval from a research ethics review committee before commencing a research project (Hammersley and Traianou, 2012). The first section of Table 41.1 lists a number of examples of such national ethics review and approval systems for the USA, United Kingdom (UK), Australia, China, the European Union, Africa, and the Middle East. Many of these regulatory systems have been adapted from US or UK models with little consideration of cultural relevance (Alahmad et al., 2012). In response to this problem, sets of principles developed specifically for research with Indigenous communities have been developed, and often added to existing RECs (see AIATSIS, 2012 for an example).

Many of the national research ethics regulatory systems include sets of guidelines for ethical research conduct which are typically based on medical research and assume a positivist quantitative research approach (see NHMRC, 2007; Ming et al., 2015). These features have generated considerable concern about the extent to which such RECs apply to other types of, and approaches to, research (see Butz, 2008). These other types of research, however, have been considered in the RECs of various disciplinary and professional associations. The second section of Table 41.1 provides websites and resources for such RECs. Many of these RECs link research ethics to professional practice ethics (see APA, 2010), recognising that research ethics cannot be isolated from a wider professional context.

This recognition that research ethics is not limited to data collection processes and research impacts on participants has also been part of discussions on research integrity. As with rise of research ethics regulation, increasing concern over issues of academic fraud and misconduct has generated national codes of academic conduct, integrity, and/ or responsible research practice (Anderson et al., 2013). While some disciplinary and professional ethics codes combine research ethics and integrity (see APA, 2010), many national regulatory bodies treat these as two separate issues (see NHMRC, 2007, 2015; UKRIO, 2009). RECs have generally focused on the treatment of research participants, while research integrity codes focus on issues related to data recording, analysis, storage, and reporting. Evidence of increasing academic misconduct has raised concerns about the negative impacts of current systems of research quality assessment and academic rewards on researchers' behaviour (Anderson et al., 2013; Fanelli, 2009). More detailed analyses of how these quality assessment and reward systems alter research practices suggest a need to extend discussions of ethical issues to all aspects and stages of research activities. 


\section{Table 41.1 Examples of research ethics regulations and codes}

National research ethics regulation systems

\begin{tabular}{ll}
\hline Country/region & Further information \\
\hline Africa & Kass et al. (2007) \\
Australia & https://www.nhmrc.gov.au/guidelines-publications/e72 \\
China & http://www.satoriproject.eu/media/4.b-Country-report-China.pdf \\
Europe & http://www.enrio.eu/codes-guidelines-3/national-codes \\
Middle East & Alahmad et al. (2012) \\
UK & http://www.rcuk.ac.uk/documents/reviews/grc/rcukpolicyandguideline \\
& songovernanceofgoodresearchpracticefebruary2013-pdf/ \\
USA & http://www.hhs.gov/ohrp/regulations-and-policy/regulations/45-cfr-46 \\
& /index.html \\
& http://www.hhs.gov/ohrp/regulations-and-policy/belmont-report/ \\
& index.html
\end{tabular}

Professional/disciplinary research ethics codes

\begin{tabular}{lc}
\hline Association & Further information \\
\hline American & http://www.aaanet.org/profdev/ethics/upload/Statement-on-Ethics- \\
Anthropological & Principles-of-Professional_Responsibility.pdf \\
Association & \\
American Association & http://www.aag.org/cs/about_aag/governance/ \\
of Geographers & statement_of_professional_ethics \\
American Political & http://www.apsanet.org/portals/54/Files/Publications/ \\
Science Association & APSAEthicsGuide2012.pdf \\
American Psychological & http://www.apa.org/ethics/code/ \\
Association & \\
American Sociological & http://www.asanet.org/sites/default/files/code_of_ethics.pdf \\
Association & http://www.amsro.com.au/amsroresp/wp-content/uploads/2014/03/ \\
Association of Market & The-Privacy-Market-and-Social-Research-Code-2014.pdf \\
and Social Research & \\
Organisations & http://www.theasa.org/ethics/guidelines.shtml \\
Association of Social & \\
Anthropologists & \\
of the UK and & \\
Commonwealth & https://acfid.asn.au/sites/site.acfid/files/resource_document/ \\
Australian Council & Principles-for-Ethical-Research-and-Evaluation-in- \\
for International & Development2016.pdf \\
Development & http://www.amsrs.com.au/professional-standards/ \\
Australian Market and & amsrs-code-of-professional-behaviour \\
Social Research & http://www.bps.org.uk/sites/default/files/documents/code_of_human_ \\
Society & research_ethics.pdf \\
British Psychological & https://www.tasa.org.au/about-tasa/ethical-guidelines/ \\
Society & \\
Marketing Research & \\
Association & \\
Australian Sociological & \\
Association & \\
\hline & \\
\hline
\end{tabular}


Combining discussions of research ethics and research integrity allows for the identification of five principles for ethical research decisions: beneficence, respect, justice, truthfulness, and research quality (Anderson et al., 2013; Hammersley and Traianou, 2012; Israel, 2015). Beneficence is a requirement to conduct research for a positive or beneficial outcome for the participants and the broader community or public. It is most often presented as non-maleficence or the absence of harm, with researchers assumed to have a duty of care towards all research stakeholders. This requires the use of detailed risk assessments and the development of plans to eliminate or mitigate any identified risks of harm to the participants and other research stakeholders.

Respect is linked to recognition that having people participate in research is a privilege, not a right, and that all research stakeholders should be respected. This is usually discussed with the concepts of autonomy, where potential participants have the right to refuse to be involved and have the freedom to withdraw from the research at any time; and informed consent, which refers to participants agreeing to be involved based on full disclosure from researchers about all relevant aspects of the proposed research.

Justice requires researchers to ensure a fair distribution of the costs and benefits of their research. Truthfulness requires researchers to be trustworthy in their dealings with all research stakeholders, to have a transparent decision process, and to be accountable for the consequences of their decisions.

Research quality refers to the need for research to be unbiased, valid, reliable, and of importance to the wider public. This is usually seen as supported by four norms for researchers, which are:

- universalism, or examination of the content of claims regardless of the characteristics of the people who make those claims, or recognition that all voices matter and political power should not equal a privileged positon in research;

- communality, or the belief that knowledge generated by research must be reported publicly;

- disinterestedness, where research must not be conducted for personal gain for the researcher; and

- organised scepticism, where all research is expected to be subjected to critical scrutiny and testing (Anderson et al., 2013; Botterill and Platenkamp, 2012; Brooks et al., 2014; Hammersley and Traianou, 2012; Israel, 2015; Richards and Munsters, 2010; Vanclay et al., 2013).

It is important to note that is not always possible in research to simultaneously satisfy all these principles, and often researchers are faced with conflict between them. For example, the norm of communality may have to be balanced against the potential that disclosure of some research results may harm the reputation of participants, or the validity of the research may depend on some degree of covert action which negates informed consent. In practice, the application of these principles can be difficult and requires careful consideration of complex trade-offs (Ryan, 2005). Guidance on these sorts of issues is not often provided in institutional regulatory codes and mechanisms. It can only be found when researchers critically reflect and report on their experiences and their responses to the range of ethical issues that arise during practice. In many social science disciplines such published reports play an important role in supporting all researchers, but especially 
those in the early stages of their career. It has been suggested that such guidance is not readily available for tourism researchers (Botterill and Platenkamp, 2012; MacCannell, 2012; Moscardo, 2010).

\section{DISCUSSION OF RESEARCH ETHICS IN TOURISM}

In 2010 the author reported on a review of tourism literature focused on discussion of research ethics in which she concluded that there was almost no discussion of research ethics in tourism (Moscardo, 2010). This review, however, was limited to three tourism journals and to explicit use of the terms 'ethics', 'ethical', and 'codes of conduct'. Arguably, discussions of research ethics might be more likely to appear in books on tourism research methods. Therefore, for the present chapter the author conducted an updated and expanded literature review which included more tourism journals (Annals of Tourism Research, Tourism Management, Journal of Travel Research, Journal of Sustainable Tourism, Tourism Analysis, Journal of Information Technology in Tourism), a broader search of Google Scholar, tourism research methods books, and a search for 'tourism' in the general ethics journals (Research Ethics, Journal of Empirical Research on Human Ethics, International Journal of Internet Research Ethics, Journal of Academic Ethics, IRB: Ethics and Human Research). Despite a wider review process, the overall conclusion that there is little explicit consideration of research ethics in tourism journals remains the same. Within the general research ethics journals tourism appeared only once in a paper on ethical issues related to studying HIV prevalence amongst Asian sex workers (Urada and Simmons, 2014). Within the tourism journals there were a small number of papers that included some consideration of research ethics, with a small but growing number focused on issues of research integrity.

Within the tourism research methods books there was coverage of ethics with a notable difference between the approaches taken in quantitative versus qualitative research texts. Research ethics as a topic was less likely to be included in quantitative texts, and when the topic was considered, the discussion tended to describe either basic principles and guidelines focused on participants or the need to adhere to research ethics regulations and institutional approval processes. These discussions rarely presented this as an area of challenge or concern. This is best summarised by a quote from Altinay and Paraskevas (2008, p. 147): 'It is highly unlikely that your research processes will affect or violate human rights, cause any kind of harm or reveal the confidential nature of the participants' involvement, however, you need to . . . follow the processes set by your institution.'

The assumption in this quote that tourism research is generally free of ethical issues is in stark contrast to the critical reflection on a range of ethical issues found in qualitative tourism research, Ryan's (2005) discussion and examples from quantitative tourism research, and those journal articles that did include some discussion of research ethics. These issues included:

- The appropriateness of the research question and the value of defining research questions with research participants and target communities (Leopold, 2011).

- The power dynamics and political processes that influence what is studied and what is ignored in tourism research (Bramwell and Lane, 2015; Tribe, 2004), including 
concerns about the pressures on academics resulting from increasing managerialism and current measures of academic performance (Hall, 2010; Fennell, 2013; Liburd, 2012; Melissen and Koens, 2016).

- Arguments about linking tourism research to action, social justice, and more ethical tourism practice (Chok, 2011; Dredge and Hales, 2012; Jamal, 2004; Phillimore and Goodson, 2004; Swain, 2004; Tribe, 2002).

- Reflection on the researcher's position in terms of having power over participants, presenting participants to others, and the conflicts of interest that can arise when researchers combine consulting with research (Adams, 2012; Botterill and Platenkamp, 2012; Chok, 2011; Feighery, 2011; Hall and Brown, 2010; Jennings, 2005; Swain, 2004).

- Concerns about reciprocity between researchers and participants, and the potential for exploitation of participants to further an academic's career (Hall, 2011a; Jennings, 2005).

- Extending considerations of harm from research beyond individual participants to their social groups and communities (Botterill and Platenkamp, 2012; Pocock et al., 2013), and highlighting the need to report back to communities (Stewart and Draper, 2009).

- Special ethical issues and requirements related to vulnerable groups such as children (Canosa and Graham, 2016; Schänzel and Smith, 2011).

- The need for greater consideration of cultural differences in responses to research participation (Ryan and Gu, 2010).

- The ethical challenges linked to particular methods such as ethnography (Hall, 2011b; Jennings, 2005), covert data collection (Chok, 2011; Miller et al., 2005), visual research methods (Rakic and Chambers, 2012), audio research methods (Jensen, 2016), the use of new technologies to track tourist movement (Spangenberg, 2014), and netnographic methods (Hall, 2011c; Mkono, 2012).

\title{
ETHICAL QUESTIONS FOR TOURISM RESEARCHERS
}

The most dangerous position is one of tacit acceptance of any paradigm without conscious and critical exploration of the choices and the implications of these choices. (Wearing et al., 2005, p. 434)

\begin{abstract}
There is consensus amongst writers both within the social science literature and within tourism that a major way to move towards ethical research practice is for researchers to be reflective and critical of their own actions. The issues raised in the previous sections, combined with wider social science discussion of research ethics issues, suggests a set of questions (see Table 41.2) that researchers have to answer about their research activities that have critical ethical dimensions. Connected to each major question are a set of additional, more detailed questions and issues to be considered. References are provided for each major question that provide more discussion of the listed issues, and examples of how researchers in tourism and other social science disciplines have responded to them. In Table 41.2 these major questions are presented in an order that is somewhat matched to the progression of a research project. This presentation order, however, is a matter of
\end{abstract}




\section{Table 41.2 Ethical dimensions of different research decisions}

\begin{tabular}{lll}
\hline $\begin{array}{l}\text { Research decision and } \\
\text { questions }\end{array}$ & Ethical principles and issues & Further reading \\
\hline
\end{tabular}

\begin{tabular}{|c|c|c|}
\hline $\begin{array}{l}\text { Why is the research } \\
\text { being done? } \\
\text { Who initiated it? } \\
\text { Who is paying for it? } \\
\text { Who benefits from it? } \\
\text { What roles does the } \\
\text { researcher play? }\end{array}$ & $\begin{array}{l}\text { Researchers need to be aware of the } \\
\text { potential for conflicts of interest and } \\
\text { avoid exploitation of participants. } \\
\text { Researchers need to understand the nature } \\
\text { of the power imbalance between } \\
\text { themselves and their research } \\
\text { participants, especially when the } \\
\text { researcher is also a consultant or } \\
\text { practitioner. } \\
\text { There is a debate about the ethics of } \\
\text { the relationship between research and } \\
\text { action, with some arguing that research } \\
\text { must contribute to social justice, and } \\
\text { others arguing that this approach can be } \\
\text { paternalistic and open to researcher bias. }\end{array}$ & $\begin{array}{l}\text { Baines et al. (2013) } \\
\text { Brooks et al. (2014) } \\
\text { Dredge and Hales (2012) } \\
\text { Eversole (2012) } \\
\text { Feighery (2011) } \\
\text { Finkelman and } \\
\quad \text { Lopez (2012) } \\
\text { Gelling and Munn- } \\
\quad \text { Giddings (2011) } \\
\text { Grimwood et al. (2012) } \\
\text { Silka (2010) } \\
\text { Turner (2010) } \\
\text { Wearing et al. (2005) }\end{array}$ \\
\hline
\end{tabular}

Is this a good research

It is important to ensure that the

Brooks et al. (2014) question?

Is it based on a systematic and extensive literature review?

Is it appropriate from the participants' perspectives?

Does it make sense in the cultural context? proposed research has not already been done, especially when researchers are working across disciplines.

It is also important that researchers consider the extent to which the question reflects their own values and worldviews, and how much these may vary from the values and worldviews of the participants.

Many of the principles included in Indigenous research codes are focused on these issues.

Gelling and Munn-

Giddings (2011)

Grimwood et al. (2012)

Hall (2011c)

Hornung (2013)

Koster et al. (2012)

Leopold (2011)

Martin and Mirraboopa (2003)

Morris (2015)

Silka (2010)

Tribe (2004)

Vanclay et al. (2013)

Who is participating in the research?

Who is included and who is left out?

Who is being burdened, and are they the main recipients of benefits?

Are the participants vulnerable in some way?

Is it an appropriate sample size?

Concerns have been raised about researchers overburdening some types of participants, either because of ease of access, or because some topics are more likely to support researcher career aspirations.

There are also issues of who is excluded from participation because of barriers of language, access, and power, and how this may affect the representativeness of research results.

For quantitative research this also includes understanding the characteristics of non-respondents, and the use of inflated sample sizes in order to increase the chance of statistically significant results.
Brooks et al. (2014)

Jennings (2005)

Nind et al. (2012)

Vanclay et al. (2013) 


\section{Table 41.2 (continued)}

\begin{tabular}{lll}
\hline $\begin{array}{l}\text { Research decision and } \\
\text { questions }\end{array}$ & Ethical principles and issues & Further reading \\
\hline
\end{tabular}

\begin{tabular}{|c|c|c|}
\hline $\begin{array}{l}\text { How will participants } \\
\text { give informed } \\
\text { consent? } \\
\text { Does the research } \\
\text { require covert } \\
\text { methods? } \\
\text { Who will give consent? } \\
\text { When will consent be } \\
\text { given and for what? } \\
\text { Is written informed } \\
\text { consent appropriate? }\end{array}$ & $\begin{array}{l}\text { There has always been considerable } \\
\text { discussion about the ethical issues } \\
\text { and options related to covert data } \\
\text { collection, where participants do not } \\
\text { know they are being researched, but } \\
\text { this has focused on methods such as } \\
\text { observation, and ethnography. New } \\
\text { issues are arising from research done } \\
\text { on and through the Internet, where } \\
\text { users now have different conceptions } \\
\text { of private and public, and where it is } \\
\text { difficult to maintain the anonymity of } \\
\text { participants. } \\
\text { Research across cultures also raises } \\
\text { issues of the idea of individual versus } \\
\text { group consent, and the need in some } \\
\text { situations to gain consent from } \\
\text { multiple stakeholders. For example, } \\
\text { research with children traditionally } \\
\text { required consent from an adult carer; } \\
\text { increasingly, it is argued that consent } \\
\text { from an appropriate adult is required, } \\
\text { but consent from is the child is also } \\
\text { necessary so that they are not coerced } \\
\text { into participation. }\end{array}$ & $\begin{array}{l}\text { Botterill and Platenkamp } \\
\quad(2012) \\
\text { Brooks et al. (2014) } \\
\text { Butz (2008) } \\
\text { Chok (2011) } \\
\text { Davidson (2008) } \\
\text { Elm (2009) } \\
\text { Haigh and Jones (2007) } \\
\text { Hall (2011c) } \\
\text { Reid and Brief (2009) } \\
\text { Zimmer (2010) }\end{array}$ \\
\hline
\end{tabular}

What are the risks of participation in the research?

For participants?

For their groups and communities?

For the researchers?

How will these risks be managed?

How will the researcher be accountable for the consequences of their research practice?
The key issues here are: the need to consider harm to a wider range of stakeholders and not just the direct participants; to extend the concept of harm beyond physical harm and psychological distress to include all dimensions of well-being such as harm to reputation and harm to relationships; and to extend the consideration of risk beyond the immediate time frame of the research, especially into longer-term impacts, and impacts that might arise from future uses of data.

This responsibility extends beyond the immediate conduct of the research and includes things such as: potential future uses of data for purposes not anticipated during the research; the need to have support services in place
Brooks et al. (2014)

Davidson (2008)

Elm (2009)

Hammersley and

Traianou (2012)

Miller et al. (2005)

Pocock et al. (2013)

Ross et al. (2010) 


\section{Table 41.2 (continued)}

Research decision and Ethical principles and issues $\quad$ Further reading
questions

for some respondents; and the need to have a system for dealing with disputes and problems that may arise.

Is this a sound and appropriate research methodology?

Is it appropriate across cultures?

What are the issues associated with specific methods?

How will the results be analysed?

How will outliers be managed?

How will emerging patterns be validated?

What decision rules will be used for excluding or including variables in analyses?

How will the results be reported?

How will participants be provided with feedback?

How will participant confidentiality be assured in the reporting?

Where will the results be published? How many papers will be published?

Who will be the authors, and why?
Recognition that not all participants may have experience with and/or be comfortable with all forms of research.

For example, the use of focus groups assumes that all participants are comfortable with expressing their views in public, and that all share the norm of not reporting to others the content of the discussions.

In addition to the traditional requirements of honesty and attention to data reliability and validity, emerging concerns include: the removal of inconvenient data; selective reporting to inflate the importance of a study or the conclusions; reporting conceptual models as if they were developed before the data analysis, when they are actually based on the results that emerged; not testing alternative models; and adding and removing variables to manipulate a significant result.

Reflects the importance of reporting back to key research stakeholders so that maximum benefits are generated and promises made to participants are kept.

Issues around ensuring that participants, and their social groups or communities, are not harmed by reports that identify them, that could be seen as portraying them negatively, or that make public information that may be culturally inappropriate to release.

Issues related to integrity such as: not producing excessive numbers of similar or small publications to boost publication profiles; choosing publication outlets based on prestige rather than potential audience exposure; inappropriate authorship, such as including people who should
Brooks et al. (2014)

Brooks et al. (2014)

Israel (2015)

Ryan (2005)

Brooks et al. (2014)

Israel (2015)

Stewart and Draper (2009)

Swain (2004) 


\section{Table 41.2 (continued)}

\begin{tabular}{ll}
\hline $\begin{array}{l}\text { Research decision and } \\
\text { questions }\end{array}$ & Ethical principles and issues
\end{tabular}

\begin{tabular}{|c|c|c|}
\hline & $\begin{array}{l}\text { not be authors, and excluding those } \\
\text { who should; and excessive citation of } \\
\text { one's own or colleagues' publications. }\end{array}$ & \\
\hline $\begin{array}{l}\text { How will the data be } \\
\text { stored and used in the } \\
\text { future? } \\
\text { Will they be available } \\
\text { for reuse by other } \\
\text { researchers? } \\
\text { How will audio and } \\
\text { visual data be stored? }\end{array}$ & $\begin{array}{l}\text { The rise of data mining and data analytic } \\
\text { tools mean that there is now pressure } \\
\text { on institutions such as universities to } \\
\text { make their data available for other } \\
\text { researchers. On the one hand, using } \\
\text { existing data can be seen as ethical as } \\
\text { it generates less burden on participants } \\
\text { and increases the potential benefits } \\
\text { from their involvement; but on the } \\
\text { other hand, it is difficult to anticipate } \\
\text { what these future uses might be, and } \\
\text { how they may be harmful to the } \\
\text { participants. } \\
\text { The increasing use of alternative forms of } \\
\text { data such as visual and audio records } \\
\text { that may have personal or cultural } \\
\text { meaning to the participants beyond the } \\
\text { study also present challenges for how } \\
\text { these forms of data are stored and by } \\
\text { whom. }\end{array}$ & $\begin{array}{l}\text { Brooks et al. (2014) } \\
\text { Nind et al. (2012) } \\
\text { Wilson (2011) }\end{array}$ \\
\hline $\begin{array}{l}\text { How will the research } \\
\text { and the ethical } \\
\text { dimensions be } \\
\text { evaluated? } \\
\text { Does the research } \\
\text { have the required } \\
\text { institutional } \\
\text { approvals? } \\
\text { How will the researcher } \\
\text { reflect upon and } \\
\text { evaluate the ethics } \\
\text { of the research as it } \\
\text { happened? }\end{array}$ & \multicolumn{2}{|c|}{$\begin{array}{l}\text { Despite genuine concerns about the extent to which institutional } \\
\text { ethics review processes are appropriate to all possible research } \\
\text { situations, especially new research approaches, it is clear that } \\
\text { they do offer a reminder and initial framework for researchers to } \\
\text { carefully consider the ethical dimensions of their decisions before } \\
\text { they begin the research. } \\
\text { The most consistent suggestion for more ethical research is for } \\
\text { researchers to engage in critical reflection about their research } \\
\text { decisions. }\end{array}$} \\
\hline
\end{tabular}

convenience rather than an attempt to prescribe a specific process, and it is important to recognise that some of these decisions may have to be revisited multiple times as the research unfolds and evolves. It is also important to recognise that at each of these decision points some or all of the general ethical principles previously listed may be relevant. The overview provided in Table 41.2 of the ethical issues involved at various stages of research reveal a number of tensions and challenges, especially when working across 
cultures, with communities, and where the researcher has multiple roles, as well as issues of dealing with new methodologies and research opportunities, especially in the online and social media worlds. The application of many of these issues can be demonstrated in two different tourism research examples. These examples were created by combining the features of several real tourism research projects that the author was involved with. The names, places, and some details have been changed to preserve the anonymity of other researchers and the participants that were involved. Further, because of space limitations the examples only describe the issue and a summary of the researcher responses, and it must be remembered that these were complex situations with considerable arguments made before a final decision was taken, and the researchers are still not entirely sure whether the final decisions were the best ones in terms of ethical dimensions.

The first example involved a larger wildlife conservation project being conducted in a remote area in a South-East Asian country, with several small villages reliant on subsistence agriculture and with limited experience of travel or strangers within their community. The conservation project was funded by a combination of development and wildlife conservation agencies and supported by the national government, and it aimed to develop a conservation and management programme for a particular wildlife species found in the region. This programme involved removing the rights of the residents to hunt and eat this species. The wildlife researchers thought that the way to compensate the local communities was to introduce luxury ecotourism. This wildlife research team approached the author and several other social scientists to conduct research to support the establishment of this alternative form of economic activity.

Preliminary site visits revealed very quickly that the communities whose rights were being taken away had not been involved in any discussions about this activity, and at no point had they been asked to consider whether or not they supported the conservation programme, or whether they felt tourism was a desirable or acceptable option. The social science team expressed considerable concern about the need for the project to reframe the research questions, to allow for the relevant communities to consider the arguments for conservation and to contemplate a wider range of options for responding to this external drive for wildlife conservation. The response of the original team was to agree to this change, but within the context of conducting a self-completion questionnairebased survey of all residents to attain a 'democratic' overview. The majority of the social science team, with the assistance of other researchers with experience of researching in this region, especially those researchers from within the country, then spent time trying to explain that this proposed method was based on a number of incorrect assumptions, including that all residents were literate, that all speak the same language, that all had sufficient experience of a cash-based economy and the nature of tourism to make informed decisions in response to short structured questions, that they had experience with surveys, that in a collective culture all residents would feel comfortable in expressing an individual opinion in the absence of detailed collective discussion (the norm for governance in these communities), that the individualised Western idea of democracy had meaning in this context, and that the community leaders would approve of such an activity.

The social science team proposed instead a more extensive process of first meeting with community leaders to establish a relationship, which would include the research team investing in the community through providing transport support for existing health staff and bringing in both their own food and extra food for the community (a strategy 
suggested by local researchers) before starting a discussion about the possibility of the conservation programme. This would be followed by more communal meetings established by the leaders to talk about how the community might benefit from the proposed conservation and ecotourism plan, but also highlighting some of the issues that had been identified with ecotourism in other communities in nearby regions. An analysis of the existing relevant tourism literature, the available infrastructure, destination image, and likely markets for the proposed luxury ecotourism venture suggested that it was highly unlikely to be a viable commercial activity, and that even if it was viable it was even more unlikely to generate sufficient benefits in a form that would replace the lost access to a vital food source.

Preliminary discussions with the community leaders confirmed many of the concerns raised by the social science team, and in one case the community refused further access to the wildlife research team. After these initial meetings and the analysis provided by the social scientists, the relationship with the original wildlife conservation group became untenable and most of the social science team withdrew from the project. Some of those who remained felt that they had a responsibility to continue to try to advocate for a more ethical approach, while others were under considerable pressure from their institutions to remain in the project because it was associated with a large grant.

The second example involved two studies comparing two different cultural groups of young people and their responses to more ethical tourism products and services. The first study was an online survey, and the second was an analysis of travel reviews and blogs with images posted on several public social networking sites. The research team consisted of several academics who were also teaching classes of general business students, and these classes were used in the online survey sample. The students were asked to participate and to send the online survey link to others, and participation was organised so that the researcher and teachers could not identify which students had or had not participated. While this meant that theoretically there was no coercion, for one cultural group the traditional relationship between teacher and student is one that gives the teacher considerable power, and the possibility of coercion still existed; therefore more effort was expended with that group to explain that participation was voluntary, and to discuss the ethical dilemma for the researcher. Despite, or perhaps because of, this there was an overall much higher rate of participation in this group compared to the other group. The questionnaire was pilot tested and that pilot test revealed some cultural differences in the way the respondents reacted to some questions. Given that the research question was about cultural comparison, considerable effort was then spent on revising the questionnaire and conducting a larger pilot study that allowed for statistical testing of different aspects of measurement and construct equivalence. Measurement equivalence is a research quality issue that has an ethical dimension, as any differences between the two groups could be interpreted as real cultural difference when they are in fact measurement errors. The second study involved a thematic analysis of online content generated by young people in the target cultural groups, seeking major responses to more ethical tourism products.

While some researchers have suggested that if these online postings are available on sites that are open to the public and do not require passwords for access then they can be used without any consent from the authors, others have argued that the people posting this information may not always consider their posts to be for public consumption and 
thus should be asked for consent to use them (see Hall, 2011c for a discussion of this issue). The researchers considered the option of contacting the authors of the material to be used, to seek consent, but found that most had posted anonymously and were not able to be contacted. Although the posts were anonymous, that does not mean that it is impossible to connect a statement to an individual, as the sharing and reposting of material can sometimes inadvertently reveal the author's identity. To avoid this the researchers did not use direct quotes or any images from the material they analysed, although this is common in traditional qualitative research.

Finally, in both studies some key findings were that young people, regardless of cultural background, had very different values than those espoused by advocates of ethical tourism. While the researchers did not feel the need to provide a value judgement on this difference, instead noting that there was a difference which might have implications in a number of areas, presentation of the results at academic conferences generated some quite negative comments from some audience members about these differences. These comments described not just the respondents, but young people in general as being unethical, careless, or selfish. This response was a shock to the researchers, who naively assumed that a difference in values was not necessarily a bad thing. The lesson learnt was the need to carefully frame the presentation of such results, and the episode highlighted the responsibility that researchers have when they represent the views of others to protect those others from criticism and judgement, even in an abstract situation.

\section{MOVING TOWARDS MORE ETHICAL TOURISM RESEARCH: CONCLUSIONS}

It is not necessary to have a specific tourism research ethics code, as numerous codes (see Table 41.1 for a small selection of those available) already exist that can be applied to tourism. Rather, it is important that tourism researchers take time to explore and apply these existing codes. It is also not enough to rely solely on institutional ethical guidelines, although a serious commitment to these processes can be an important first step in thinking about the ethical issues that might be relevant to a research study. Rather, the two most critical steps required to move towards more ethical tourism research are the publication of more papers on tourism research ethics, and the encouragement of discussion and debate on these matters. MacCannell (2012, p. 185) argues that 'a research domain without ethical reflexivity, that refuses to come to grips with itself and its subject matter in ethical terms is doomed to failure', highlighting the most common suggestion for improving ethical research practice, which is public critical reflection and discussion of the ethical dilemmas that researchers face and how they respond to them. It is hoped that this chapter has made some contribution to this tradition.

\section{REFERENCES}

Adams, K.M. (2012). Ethnographic methods. In L. Dwyer, A. Gill, and N. Seetaram (eds), Handbook of Research Methods in Tourism: Quantitative and Qualitative Applications (pp. 339-364). Cheltenham, UK and Northampton, MA, USA: Edward Elgar Publishing. 
AIATSIS (2012). Guidelines for ethical research in Australian indigenous studies. http://aiatsis.gov.au/sites/ default/files/docs/research-and-guides/ethics/gerais.pdf.

Alahmad, G., Al-Jumah, M., and Dierickx, K. (2012). Review of national research ethics regulations and guidelines in Middle Eastern Arab countries. BMC Medical Ethics, 13(1), 1-10.

Altinay, L., and Paraskevas, A. (2008). Planning Research in Hospitality and Tourism. Philadephia, PA: Taylor \& Francis.

Anderson, M.S., Shaw, M.A., Steneck, N.H., Konkle, E., and Kamata, T. (2013). Research integrity and misconduct in the academic profession. In M.B. Paulsen (ed.), Higher Education: Handbook of Theory and Research (pp. 217-261). Dordrecht: Springer Netherlands.

APA (2010). Ethical principles for psychologists and Code of Conduct. Accessed April 2016 at http://www.apa. org/ethics/code/.

Baines, J.T., Taylor, C.N., and Vanclay, F. (2013). Social impact assessment and ethical research principles: ethical professional practice in impact assessment. Part II. Impact Assessment and Project Appraisal, 31(4), 254-260.

Botterill, D., and Platenkamp, V. (2012). Key Concepts in Tourism Research. London: SAGE.

Bramwell, B., and Lane, B. (2015). What drives research on sustainable tourism?. Journal of Sustainable Tourism, 23(1), 1-3.

Brooks, R., te Riele, K. and Maguire, M. (2014). Ethics and Education Research. London: SAGE.

Butz, D. (2008). Sidelined by the guidelines: Reflections on the limitations of standard informed consent procedures for the conduct of ethical research. ACME: An International E-Journal for Critical Geographies, 7(2), 239-259.

Canosa, A., and Graham, A. (2016). Ethical tourism research involving children. Annals of Tourism Research, $61,219-221$.

Chok, S. (2011). The visible/invisible researcher: Ethics and politically sensitive research. In C.M. Hall (ed.), Fieldwork in Tourism (pp. 55-69). London: Routledge.

Davidson, J.O.C. (2008). If no means no, does yes mean yes? Consenting to research intimacies. History of the Human Sciences, 21(4), 49-67.

Dredge, D., and Hales, R. (2012). Community case study research. In L. Dwyer, A. Gill, and N. Seetaram (eds), Handbook of Research Methods in Tourism: Quantitative and Qualitative Applications (pp.417-437). Cheltenham, UK and Northampton, MA, USA: Edward Elgar Publishing.

Elm, M.S. (2009). How do various notions of privacy influence decisions in qualitative internet research?. In A.N. Markham and N.K. Baym (eds), Internet Inquiry: Conversations about Method (pp. 69-87). Los Angeles, CA: SAGE.

Eversole, R. (2012). Remaking participation: challenges for community development practice. Community Development Journal, 47(1), 29-41.

Fanelli, D. (2009). How many scientists fabricate and falsify research? A systematic review and meta-analysis of survey data. PloS One, 4(5), e5738.

Feighery, W.G. (2011). Consulting ethics. Annals of Tourism Research, 38(3), 1031-1050.

Fennell, D.A. (2006). Tourism Ethics. Clevedon: Channel View.

Fennell, D. (2013). The ethics of excellence in tourism research. Journal of Travel Research, 52(4), 417-425.

Finkelman, J., and Lopez, P.D. (2012). Global consulting in a culturally diverse world: Ethical and legal implications. Consulting Psychology Journal: Practice and Research, 64(4), 307-324.

Gelling, L., and Munn-Giddings, C. (2011). Ethical review of action research: The challenges for researchers and research ethics committees. Research Ethics, 7(3), 100-106.

Grimwood, B.S., Doubleday, N.C., Ljubicic, G.J., Donaldson, S.G., and Blangy, S. (2012). Engaged acclimatization: Towards responsible community-based participatory research in Nunavut. Canadian Geographer / Géographe Canadien, 56(2), 211-230.

Haigh, C., and Jones, N. (2007). Techno-research and cyber-ethics: challenges for ethics committees. Research Ethics Review, 3(3), 80-83.

Hall, C.M. (2010). Academic capitalism, academic responsibility and tourism academics: Or, the silence of the lambs?. Tourism Recreation Research, 35(3), 298-301.

Hall, C.M. (2011a). Fieldwork in tourism/tourism fields: Where does tourism end and fieldwork begin?. In C.M. Hall (ed.), Fieldwork in Tourism (pp. 7-18). London: Routledge.

Hall, C.M. (2011b). Researching the political in tourism: Where knowledge meets power. In C.M. Hall (ed.), Fieldwork in Tourism (pp. 39-54). London: Routledge.

Hall, C.M. (2011c). In cyberspace can anybody hear you scream? Issues in the conduct of online fieldwork. In C.M. Hall (ed.), Fieldwork in Tourism (pp. 265-288). London: Routledge.

Hall, D., and Brown, F. (2010). 'Post-colonialism', responsibility and tourism academics: Where's the connection? Tourism Recreation Research, 35(3), 291-297.

Hammersley, M. and Traianou, A. (2012). Qualitative Research Ethics: Controversies and Contexts. London: SAGE. Hornung, F. (2013). Indigenous research with a cultural context. In D.M. Mertens, F. Cram, and B. Chilisa 
(eds), Indigenous Pathways into Social Research: Voices of a New Generation (pp. 133-152). Walnut Creek, CA: Left Coast Press.

Ioannidis, J.P. (2005). Why most published research findings are false. PLoS Medicine, 2(8), e124.

Israel, M. (2015). Research Ethics and Integrity for Social Scientists: Beyond Regulatory Compliance, 2nd edn. Los Angeles, CA: SAGE.

Jamal, T.B. (2004). Virtue ethics and sustainable tourism pedagogy: Phronesis, principles and practice. Journal of Sustainable Tourism, 12(4), 530-545.

Jennings, G.R. (2005). Interviewing: A focus on qualitative techniques. In B.W. Ritchie, P. Burns, and C. Palmer (eds), Tourism Research Methods: Integrating Theory with Practice (pp.99-118). Wallingford: CABI.

Jensen, M.T. (2016). Tourism research and audio methods. Annals of Tourism Research, 56, 158-160.

Kass, N.E., Hyder, A.A., Ajuwon, A., et al. (2007). The structure and function of research ethics committees in Africa: A case study. PLoS Med, 4(1), e3.

Koster, R., Baccar, K., and Lemelin, R.H. (2012). Moving from research ON, to research WITH and FOR Indigenous communities: A critical reflection on community-based participatory research. Canadian Geographer / Géographe Canadien, 56(2), 195-210.

Leopold, T. (2011). Reflexivity and ethnography in community tourism research. In C.M. Hall (ed.), Fieldwork in Tourism (pp. 87-98). London: Routledge.

Liburd, J.J. (2012). Tourism research 2.0. Annals of Tourism Research, 39(2), 883-907.

MacCannell, D. (2012). On the ethical stake in tourism research. Tourism Geographies, 14(1), 183-194.

Martin, K., and Mirraboopa, B. (2003). Ways of knowing, being and doing: A theoretical framework and methods for indigenous and indigenist re-search. Journal of Australian Studies, 27(76), 203-214.

Melissen, F., and Koens, K. (2016). Adding researchers' behaviour to the research agenda: Bridging the science-policy gap in sustainable tourism mobility. Journal of Sustainable Tourism, 24(3), 335-349.

Miller, G., Hudson, S., and Turner, R. (2005). Applying the mystery shopping technique: The case of Lunn Poly. In B.W. Ritchie, P. Burns, and C. Palmer (eds), Tourism Research Methods: Integrating Theory with Practice (pp. 119-130). Wallingford: CABI.

Ming, X., Douglas, D., Gurzawska, A., and Brey, P. (2015). Ethics assessment in different countries: China. Accessed October 2016 at http://www.satoriproject.eu/media/4.b-Country-report-China.pdf.

Mkono, M. (2012). Netnographic tourist research: The internet as a virtual fieldwork site. Tourism Analysis, 17(4), 553-555.

Morris, N. (2015). Providing ethical guidance for collaborative research in developing countries. Research Ethics, 11(4), 211-235.

Moscardo, G. (2010). Tourism research ethics: Current considerations and future options. In D.G. Pearce and R.W. Butler (eds), Tourism Research: A 20-20 Vision (pp. 203-214). Woodeaton: Goodfellow.

Moscardo, G. (2014). Do tourists travel for the discovery of 'Self' or search for the 'Other'?. Tourism Recreation Research, 39(1), 82-92.

NHMRC (2007). Australian Code for the Responsible Conduct of Research. Accessed April 2016 at https:// www.nhmrc.gov.au/_files_nhmrc/publications/attachments/r39.pdf?.

NHMRC (2015). National Statement on Ethical Conduct in Human Research (2007) - Updated May 2015. Accessed April 2016 at https://www.nhmrc.gov.au/guidelines-publications/e72.

Nind, M., Wiles, R., Bengry-Howell, A., and Crow, G. (2012). Methodological innovation and research ethics: Forces in tension or forces in harmony?. Qualitative Research, 13(6), 650-667.

Phillimore, J., and Goodson, L. (2004). From ontology, epistemology and methodology to the field. In J. Phillimore and L. Goodson (eds), Qualitative Research in Tourism (pp. 185-194). London: Routledge.

Pocock, N., Cockburn-Wootten, C., and McIntosh, A. (2013). Significant other voices in tourism research. Annals of Tourism Research, 41, 240-243.

Rakic, T., and Chambers, J. (2012). Introducing visual methods in tourism studied. In T. Rajic and J. Chambers (eds), An Introduction to Visual Research Methods in Tourism (pp. 3-14). Abingdon: Routledge.

Reid, C., and Brief, E. (2009). Confronting condescending ethics: How community-based research challenges traditional approaches to consent, confidentiality, and capacity. Journal of Academic Ethics, 7(1/2), 75-85.

Richards, G., and Munsters, W. (2010). Cultural Tourism Research Methods. Wallingford: CABI.

Ross, L.F., Loup, A., Nelson, R.M., et al. (2010). Human subjects protections in community-engaged research: A research ethics framework. Journal of Empirical Research on Human Research Ethics, 5(1), 5-17.

Ryan, C. (2005). Ethics in tourism research: Objectivities and personal perspectives. In B. Ritchie, P. Burns, and C. Palmer (eds), Tourism Research Methods: Integrating Theory with Practice, 9-19. Wallingford: CABI.

Ryan, C., and Gu, H. (2010). Constructionism and culture in research: Understandings of the fourth Buddhist Festival, Wutaishan, China. Tourism Management, 31(2), 167-178.

Schänzel, H.A., and Smith, K.A. (2011). Photography and children: Auto-driven photo-elicitation. Tourism Recreation Research, 36(1), 81-85.

Silka, L. (2010). Community research in other contexts: Learning from sustainability science. Journal of Empirical Research on Human Research Ethics, 5(4), 3-11. 


\section{Handbook of research methods for tourism and hospitality management}

Spangenberg, T. (2014). Development of a mobile toolkit to support research on human mobility behavior using GPS trajectories. Information Technology and Tourism, 14(4), 317-346.

Stewart, E.J., and Draper, D. (2009). Reporting back research findings: a case study of community-based tourism research in northern Canada. Journal of Ecotourism, 8(2), 128-143.

Swain, M.B. (2004). Disembodied experience and power dynamics in tourism research. In J. Phillimore and L. Goodson (eds), Qualitative Research in Tourism (pp. 102-118). London: Routledge.

Tribe, J. (2002). Education for ethical tourism action. Journal of Sustainable Tourism, 10(4), 309-324.

Tribe, J. (2004). Knowing about tourism: Epistemological issues. In J. Phillimore and L. Goodson (eds), Qualitative Research in Tourism (pp.46-62). London: Routledge.

Turner, S. (2010). Challenges and dilemmas: fieldwork with upland minorities in socialist Vietnam, Laos and southwest China. Asia Pacific Viewpoint, 51(2), 121-134.

UKRIO (2009). Code of Practice for Research. Accessed April 2016 at http://ukrio.org/wp-content/uploads/ UKRIO-Code-of-Practice-for-Research.pdf.

Urada, L.A., and Simmons, J. (2014). Social and structural constraints on disclosure and informed consent for HIV survey research involving female sex workers and their bar managers in the Philippines. Journal of Empirical Research on Human Research Ethics, 9(1), 29-40.

Vanclay, F., Baines, J.T., and Taylor, C.N. (2013). Principles for ethical research involving humans: Ethical professional practice in impact assessment. Part I. Impact Assessment and Project Appraisal, 31(4), 243-253.

Wearing, S., McDonald, M., and Ponting, J. (2005). Building a decommodified research paradigm in tourism: The contribution of NGOs. Journal of Sustainable Tourism, 13(5), 424-439.

Wilson, J. (2011). Freedom of information and research data. Research Ethics, 7(3), 107-111.

Zimmer, M. (2010). 'But the data is already public': On the ethics of research in Facebook. Ethics and Information Technology, 12(4), 313-325.

\section{Further Reading}

Botterill, D., and Platenkamp, V. (2012). Key Concepts in Tourism Research. London: SAGE. This text offers a comprehensive and critical discussion of research ethics principles and applications for tourism.

Israel, M. (2015). Research Ethics and Integrity for Social Scientists: Beyond Regulatory Compliance, 2nd edn. Los Angeles, CA: SAGE. This book provides detailed guidance for traditional research ethics questions and describes a number of research integrity issues. 